\title{
Influence at Mass of the Base Isolation System in Affecting the Higher Modes of Vibration
}

\section{Cici Jennifer Raj $\mathbf{J}^{1 *}$ and Vinod Kumar $\mathbf{M}^{2}$}

${ }^{1}$ Research Scholar, Vel Tech Rangarajan Dr.Sagunthala R \& D Institute of Science \& Technology, Department of Civil Engineering, 600062, Avadi, Chennai, India.

${ }^{2}$ Associate Professor, Vel Tech Rangarajan Dr.Sagunthala R \& D Institute of Science \& Technology, Department of Civil Engineering, 600062, Avadi, Chennai, India.

Article History: Received: 10 November 2020; Revised: 12 January 2021; Accepted: 27 January 2021; Published online: 05 April 2021

\begin{abstract}
Base Isolation is a technology of mitigating the effects due to earthquakes with the aspect of dissipating the seismic waves away from the superstructure, by isolating the superstructure from the ground.This concept is widely essential to be implemented in structures(buildings) irrespective of many factors. There are several materials which could be implemented as base isolator, however the need in reduction of the number of the isolators is essential dueto various factors which a developing country finds difficult to implement. In this paper, a three-storey unsymmetrical building to be considered for the study is isolated by varying the mass of the foundation beam, (Transfer beam) thereby reducing the number of isolators in the building.Furthermore,the mode shapes and frequencies of the structure without base isolation and with base isolation considering mass of the base isolation system as a key factor were analysed and compared and hence the variation in the mass of the isolation system has a promising effect in altering the higher modes of vibration. The analysis is prolonged using another methd using UBC-1997 provisions and compared. In both the methods, the influence of the mass of the isolation system has a remarkable effect in altering the higher modes of vibration.
\end{abstract}

Keywords: Base Isolation, Mass of the Isolation System, Higher modes, MATLAB, UBC-97, ETABS.

\section{Introduction}

The consideration of higher mode effect is neglected in many of the design codes but the contribution of higer modes is very important exclusively for taller buildings. Moreover, in initial stages, higher modes causes overturning effect but it vanishes at the end [1]. The influence of higher modes have an effect in drift and acceleration of the base slab[2]. The higher frequency modes respond in static state during low frequencies. The contribution of higher mode is significant for the lateral force distribution during seismic action [3].The research was conducted to study the effect of higher mode is in affecting the vertical distribution of base shear in an isolated structure under disatarous earthqaukes. Furthermore, the non-linear behaviour isolation systems which causes variation in frequencies transmitted to the superstructure is also significantly depend on higher modes [4]. The contribution of higher modes is higly important for a base-isolated building rather than a non-isolated building. The effect of higher modes aid in shifting of the fundamental modes of the region of dominant earthquake energy and hence the damping of the structure is enhanced [5]. The dominant variation in fundamental mode is attained with a three-storey symmetrical building with STRP as the isolator and considering stiffness as the major parameter for the analysis and the authors concluded that only fundamental mode experiences anticipated change for the material considered[6].The objective of this study is to investigate the performance of a 3-storey unsymmetrical residential building located in a severe seismic prone area with the application of base isolation system. The soil at the site is of medium type. The response of this building with fixed base using seismic coefficient method has been reported elsewhere [7]. In the present investigation, the variation of higher modes are validated by varying the mass of the isolation system and compared with design principles using UBC-1997 provisions.

\section{Proposed Methodology}

The building considered for the analysis is a three-storey unsymmetrical building located in Seismic zone IV. The structure is a moment-resisting frame. The properties of the building element are presented in Table.1. The building is a residential building with three bays in $\mathrm{X}$-direction and two bays in Y direction. The height of each storey is $3 \mathrm{~m}$ each. The investigation on the seismic isolation using Scrap tire rubber pads was analyzed and the authors eventually concluded that there is an anticipated change in first mode only [6] with the implementation of STRP bearing as the base isolator. This aspect has been significantly considered for the analysis. The investigation is enhanced by the reduction in the number of base isolators despite of the type of the isolators with the variations in mass of the isolation system. The study consists of varying the mass of the isolation system in six different cases. For instance, the building is analysed for the fixed base. The second case consists of analysis 
of the base isolated building with six different variations in the mass of the isolation system. The analysis is also enriched by the application of UBC-97 provisions[8] and ETABS Software[9], where the mode values are reported therein.

Table 1. Properties of the building [7]

\begin{tabular}{|l|l|l|}
\hline S.No & Properties & Values \\
\hline 1 & Yield strength of steel, $\mathrm{f}_{\mathrm{y}}$ & $415 \mathrm{Mpa}$ \\
\hline 2 & Compressive strength of concrete & $20 \mathrm{Mpa}$ \\
\hline 3 & Thickness of peripheral walls & $230 \mathrm{~mm}$ \\
\hline 4 & Thickness of internal walls & $115 \mathrm{~mm}$ \\
\hline 5 & Density of Brick Masonry & $20 \mathrm{kN} / \mathrm{m}^{3}$ \\
\hline 6 & Density of concrete & $25 \mathrm{kN} / \mathrm{m}^{3}$ \\
\hline 7 & Live load on roof & $1.5 \mathrm{kN} / \mathrm{m}^{2}$ \\
\hline 8 & Live load on roof & $20 \mathrm{Mpa}$ \\
\hline
\end{tabular}

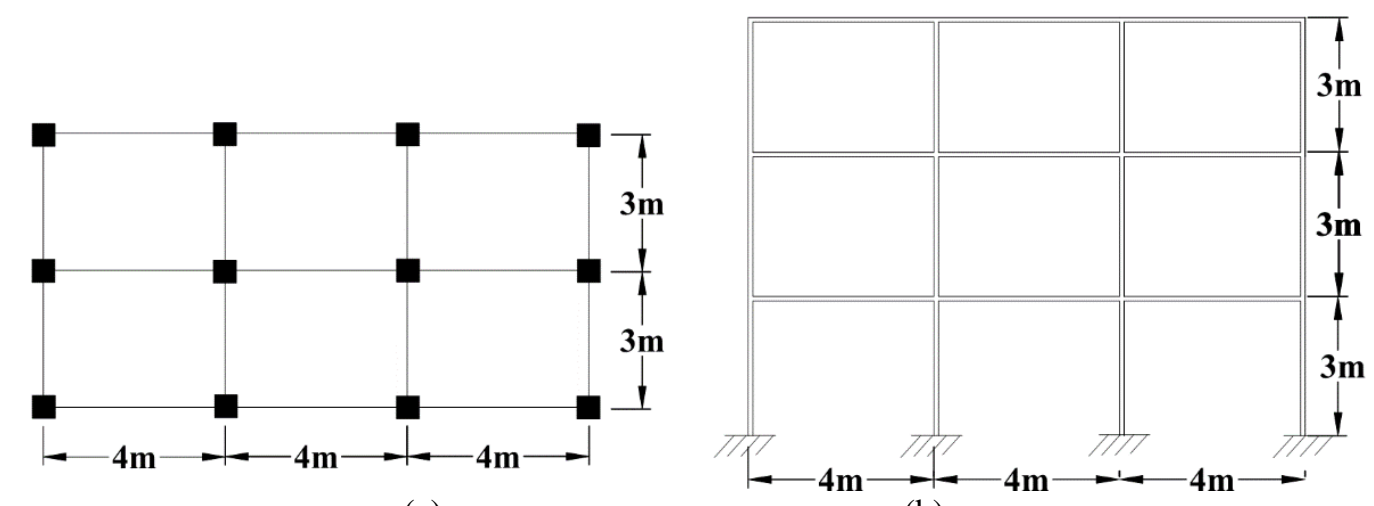

(a)

(b)

Figure 1. RC Residential Building (a) Plan of the building(d) Elevation of the building [7]

\subsection{Analysis for the fixed Base building}

From the properties in Table.1, the arrived values of stiffness and mass in each stories are $\mathrm{k}_{1}=\mathrm{k}_{2}=4.600$ $\mathrm{x} 10^{4} \mathrm{kN} / \mathrm{m}, \mathrm{k}_{3}=2.6178 \times 10^{4} \mathrm{kN} / \mathrm{m} ., \mathrm{m}_{1}=150.85 \mathrm{kNs}^{2} / \mathrm{m}, \mathrm{m}_{2}=150.85 \mathrm{KNs}^{2} / \mathrm{m}$ and $\mathrm{m}_{3}=89.17 \mathrm{KNs}^{2} / \mathrm{m}$.

The system of equation (neglecting damping) is given as $[6,10]$

$$
\mathrm{M} \ddot{x}+\mathrm{K} x=0 \quad \text { Equation (1) }
$$

The characteristic equation is given as

$$
\left|[\mathrm{K}]-\omega_{\mathrm{n}}^{2}[\mathrm{M}]\right|=0
$$

The parameters in Equation(1) and Equation 1(a) are reported in [6, 10]

The values of the mass and stiffness is substituted [10] in eq.1a to $1 \mathrm{~b}$, the dynamic properties of the building is presented in Table. 2

Mass Matrix

$$
\mathrm{M}=\left[\begin{array}{ccc}
\mathrm{m}_{1} & 0 & 0 \\
0 & \mathrm{~m}_{2} & 0 \\
0 & 0 & \mathrm{~m}_{3}
\end{array}\right] \quad \mathrm{kNs}^{2} / \mathrm{m}
$$

Stiffness Matrix

$$
\mathrm{K}=\left[\begin{array}{ccc}
k_{1}+k_{2} & -k_{2} & 0 \\
-k_{2} & k_{2}+k_{3} & -k_{3} \\
0 & k_{3} & k_{3}
\end{array}\right]
$$

Mass Matrix

$$
\mathrm{M}=\left[\begin{array}{ccc}
150.85 & 0 & 0 \\
0 & 150.85 & 0 \\
0 & 0 & 89.17
\end{array}\right] \mathrm{kNs}^{2} / \mathrm{m}
$$

Stiffness Matrix

$$
\mathrm{K}=\left[\begin{array}{ccc}
920052 & -460062 & 0 \\
-460062 & 721806 & -261780 \\
0 & -261780 & 261780
\end{array}\right] \mathrm{kN} / \mathrm{m}
$$


Table 2. Dynamic Properties of Fixed-Base Building

\begin{tabular}{|l|c|c|c|}
\hline Mode & 1 & 2 & 3 \\
\hline Frequency $(\mathrm{Hz})$ & 4.3161 & 10.2633 & 15.0365 \\
\hline Mode Shape & 1.0000 & 1.0000 & 1.0000 \\
\cline { 2 - 4 } & 1.7587 & 0.6363 & -0.9269 \\
\cline { 2 - 4 } & 2.3465 & -1.5277 & 0.4543 \\
\hline
\end{tabular}

\subsection{Analysis for Base isolated building}

\subsubsection{Method 1: Varying of Mass of the isolation system}

The concept of reducing the number of number of isolators is briefed in NZ Draft [11] in which the size of the transfer beam could be modified thereby reducing the number of isolators significantly. The illustrated picture is shown in Figure.2. This concept is evaluated with the mass of the transfer beam and substantially the participation of higher modes which is essential for the current research is established.

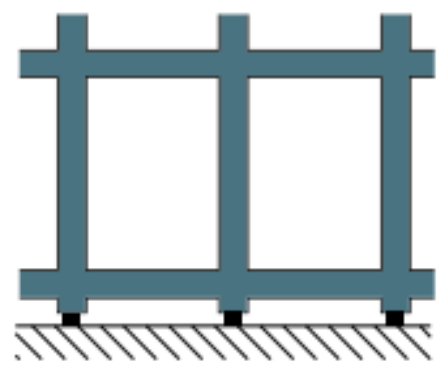

(a)

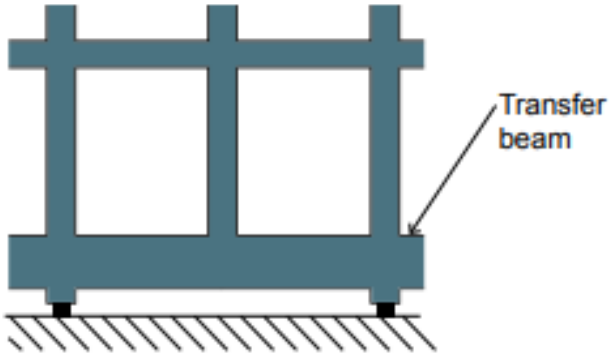

(b)

Figure 2. (a) Frame without change in Transfer beam (b) Frame with change in Transfer beam [11]

The solution of this equation is given by [10]:
$[\mathrm{M}]_{\mathrm{c}}\{\ddot{\mathrm{v}}\}+[\mathrm{C}]_{\mathrm{c}}\{\dot{\mathrm{v}}\}+[\mathrm{K}]_{\mathrm{c}}\{\mathrm{v}\}=-[\mathrm{M}]_{\mathrm{C}}\{\mathrm{r}\}_{\mathrm{c}} \ddot{\mathrm{u}}_{\mathrm{g}}$
Equation 2

For instance the stiffness of the bearing and the mass of the isolation varies for different cases. The stiffness of the isolator $\left(\mathrm{k}_{\mathrm{b}}\right)$ is computed based on the equation 1 .

$$
\mathrm{k}_{\mathrm{b}}=\mathrm{m}_{\mathrm{b}} \mathrm{x}\left(\left(\frac{2 \pi}{T_{D}}\right)^{2}\right) \longrightarrow \quad \text { Equation 2(a) }
$$

Where $T_{D}$ is the design Time Period and taken as 2.5 seconds [12], $\mathrm{m}_{\mathrm{b}}$ is the mass of the isolation system. The determination of stiffness of the isolator for different cases are computed and presented in Table.1
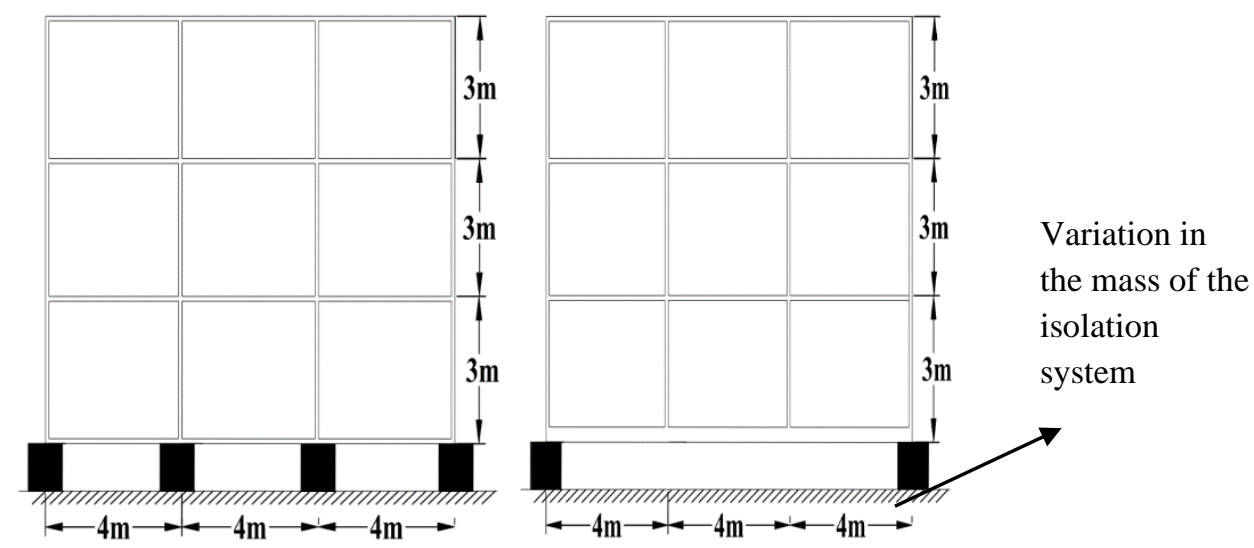

Figure 3. (a) No Variation in the mass of the isolation system (b) Variation in the mass of the isolation system.

The analysis consists of varying the mass of the isolation system in six different probabilities to spot the variations in time period and frequencies other than fundamental period and fundamental frequencies respectively. The modal analysis is performed as per the equation $2 \mathrm{a}$ to $2 \mathrm{e}$ for different cases by the variation of the mass of the isolation system [13].

Mass Matrix

$$
\mathbf{M}=\left[\begin{array}{ccc}
m_{1} & 0 & 0 \\
0 & m_{2} & 0 \\
0 & 0 & m_{3}
\end{array}\right]
$$

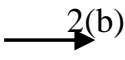


Stiffness Matrix

$$
\mathrm{K}=\left[\begin{array}{ccc}
\mathrm{k}_{1}+\mathrm{k}_{2} & -\mathrm{k}_{2} & 0 \\
-\mathrm{k}_{2} & \mathrm{k}_{2}+\mathrm{k}_{3} & -\mathrm{k}_{3} \\
0 & \mathrm{k}_{3} & \mathrm{k}_{3}
\end{array}\right]
$$

Combined Mass Matrix

$$
M_{c}=\left[\begin{array}{cccc}
M & m_{1} & m_{2} & m_{3} \\
m_{1} & m_{1} & 0 & 0 \\
m_{2} & 0 & m_{2} & 0 \\
m_{3} & 0 & 0 & m_{3}
\end{array}\right]
$$

Where $m_{s}=$ mass of the isolation system and $\quad M_{c}=m_{s}+m_{b}$, where, $m_{s}=m_{1}+m_{2}+m_{3}$

The cases are $m_{b}=m_{s}, m_{b}=1 / 4 m_{s}, m_{b}=2 / 3 m_{s}, m_{b}=1 / 2 m_{s}, m_{b}=2 m_{s} m_{b}=m_{s}, m_{b}=3 m_{s}$ $\mathrm{M}=\mathrm{m}_{\mathrm{b}}+\mathrm{m}_{\mathrm{s}}$

It is assumed that the value of $\mathrm{m}_{\mathrm{b}}<\mathrm{m}_{\mathrm{s}}$ but are of same magnitude [14].

Combined Stiffness Matrix $\quad \mathrm{K}_{\mathrm{c}}=\left[\begin{array}{cccc}\mathrm{k}_{\mathrm{b}} & 0 & 0 & 0 \\ 0 & \mathrm{k}_{1}+\mathrm{k}_{2} & -\mathrm{k}_{2} & 0 \\ 0 & -\mathrm{k}_{2} & \mathrm{k}_{2}+\mathrm{k}_{3} & -\mathrm{k}_{3} \\ 0 & 0 & -\mathrm{k}_{3} & \mathrm{k}_{3}\end{array}\right]$ 2(e)

The values of the mass and stiffness is substituted in eq.2a to $2 \mathrm{e}$, the dynamic properties of the building is presented for six different cases are reported in Table.3, Table.4, Table.5, Table.6, Table.7 and Table.8 respectively.

Table 3. Dynamic Properties of Base Isolated Building $\left(\mathrm{m}_{\mathrm{b}}=\mathrm{m}_{\mathrm{s}}\right)$

\begin{tabular}{|l|c|c|c|c|}
\hline Mode & 1 & 2 & 3 & 4 \\
\hline Frequency (Hz) & 0.2826 & 5.7875 & 10.6943 & 15.2343 \\
\hline \multirow{4}{*}{ Mode Shape } & 1.0000 & 1.0000 & 1.0000 & 1.0000 \\
\cline { 2 - 5 } & 0.0027 & -1.1184 & -3.8315 & -7.7798 \\
\cline { 2 - 5 } & 0.0043 & -2.1853 & -3.4705 & 4.8096 \\
\cline { 2 - 5 } & 0.0054 & -3.1569 & 3.5923 & -3.7392 \\
\hline
\end{tabular}

Table 4. Dynamic Properties of Base Isolated Building $\left(m_{b}=\frac{1}{2} m_{s}\right)$

\begin{tabular}{|l|c|c|c|c|}
\hline Mode & 1 & 2 & 3 & 4 \\
\hline Frequency $(\mathrm{Hz})$ & 0.2308 & 6.6558 & 11.1946 & 15.4971 \\
\hline \multirow{3}{*}{ Mode Shape } & 1.0000 & 1.0000 & 1.0000 & 1.0000 \\
\cline { 2 - 5 } & 0.0018 & -0.7405 & -2.0996 & -4.0255 \\
\cline { 2 - 5 } & 0.0029 & -1.6297 & -2.4151 & 1.3553 \\
\cline { 2 - 5 } & 0.0036 & -2.5576 & 1.0651 & -2.0564 \\
\hline
\end{tabular}

Table 5. Dynamic Properties of Base Isolated Building $\left(\mathrm{m}_{\mathrm{b}}=\frac{2}{3} \mathrm{~m}_{\mathrm{s}}\right)$

\begin{tabular}{|l|c|c|c|c|}
\hline Mode & 1 & 2 & 3 & 4 \\
\hline Frequency $(\mathrm{Hz})$ & 0.2527 & 6.2751 & 10.9393 & 15.3565 \\
\hline \multirow{4}{*}{ Mode Shape } & 1.0000 & 1.0000 & 1.0000 & 1.0000 \\
\cline { 2 - 5 } & 0.0021 & -0.8772 & -2.6729 & -5.2702 \\
\cline { 2 - 5 } & 0.0035 & -1.8169 & -2.7540 & 2.4956 \\
\cline { 2 - 5 } & 0.0043 & -2.7363 & 1.8789 & -2.6100 \\
\hline
\end{tabular}

Table 6. Dynamic Properties of Base Isolated Building $\left(\mathrm{m}_{\mathrm{b}}=\frac{1}{4} \mathrm{~m}_{\mathrm{s}}\right)$

\begin{tabular}{|l|c|c|c|c|}
\hline Mode & 1 & 2 & 3 & 4 \\
\hline Frequency (Hz) & 0.1788 & 7.8567 & 12.6960 & 17.1277 \\
\hline \multirow{4}{*}{ Mode Shape } & 1.0000 & 1.0000 & 1.0000 & 1.0000 \\
\cline { 2 - 5 } & 0.0011 & -0.3706 & -0.9696 & -1.7655 \\
\cline { 2 - 5 } & 0.0017 & -1.2440 & -2.0025 & -0.6239 \\
\cline { 2 - 5 } & 0.0022 & -2.4362 & -0.1414 & -1.1277 \\
\hline
\end{tabular}


Table 7. Dynamic Properties of Base Isolated Building $\left(\mathrm{m}_{\mathrm{b}}=2 \mathrm{~m}_{\mathrm{s}}\right)$

\begin{tabular}{|l|c|c|c|c|}
\hline Mode & 1 & 2 & 3 & 4 \\
\hline Frequency $(\mathrm{Hz})$ & 0.3263 & 5.220 & 10.4874 & 15.1375 \\
\hline \multirow{4}{*}{ Mode Shape } & 1.0000 & 1.0000 & 1.0000 & 1.0000 \\
\cline { 2 - 5 } & 0.0036 & -1.6649 & -6.7453 & -14.0625 \\
\cline { 2 - 5 } & 0.0058 & -3.0949 & -5.3099 & 10.6229 \\
\cline { 2 - 5 } & 0.0072 & -4.3079 & 7.9972 & -6.5841 \\
\hline
\end{tabular}

Table 8. Dynamic Properties of Base Isolated Building $\left(\mathrm{m}_{\mathrm{b}}=3 \mathrm{~m}_{\mathrm{s}}\right)$

\begin{tabular}{|l|c|c|c|c|}
\hline Mode & 1 & 2 & 3 & 4 \\
\hline Frequency (Hz) & 0.3461 & 4.9468 & 10.4079 & 15.1014 \\
\hline \multirow{5}{*}{ Mode Shape } & 1.0000 & 1.0000 & 1.0000 & 1.0000 \\
\cline { 2 - 5 } & 0.0040 & -2.2627 & -10.0674 & -21.2087 \\
\cline { 2 - 5 } & 0.0065 & -4.1250 & -7.4188 & 17.2426 \\
\cline { 2 - 5 } & 0.0082 & -5.6577 & 13.0549 & -9.8269 \\
\hline
\end{tabular}

\subsubsection{Method 2: As per UBC-97 Code provisions}

The system with base isolation shown in Fig. 1(d) is represented by Equation (3). The solution of this equation is given by [10]:

$[\mathrm{M}]_{\mathrm{c}}\{\ddot{\mathrm{v}}\}+[\mathrm{C}]_{\mathrm{c}}\{\dot{\mathrm{v}}\}+[\mathrm{K}]_{\mathrm{c}}\{\mathrm{v}\}=-[\mathrm{M}]_{\mathrm{C}}\{\mathrm{r}\}_{\mathrm{c}} \ddot{\mathrm{u}}_{\mathrm{g}}$

$\longrightarrow$ Equation 3

The Maximum Vertical Load (for each column) at the base of the structure are determined from ETABS Software (Static Analysis) [15] which is denoted as $\mathrm{V}_{1}, \mathrm{~V}_{2}, \mathrm{~V}_{3}$ and $\mathrm{V}_{4}$. The stiffness of each of the column with respect to the column loads are determined using the expression,

$$
\mathrm{K}_{\mathrm{eff}}=\mathrm{mx}\left(\left(\frac{2 \pi}{\mathrm{T}_{\mathrm{D}}}\right)^{2}\right)[10,15] \quad \longrightarrow \quad \text { Equation }(3 \mathrm{a})
$$

where $\mathrm{k}_{\mathrm{b}}$ is the bearing stiffness, $\mathrm{m}$ is the mass of the isolation system and $\mathrm{T}_{\mathrm{D}}$ is the Target Design Time Period (Here it is 2.5 secs) [12].

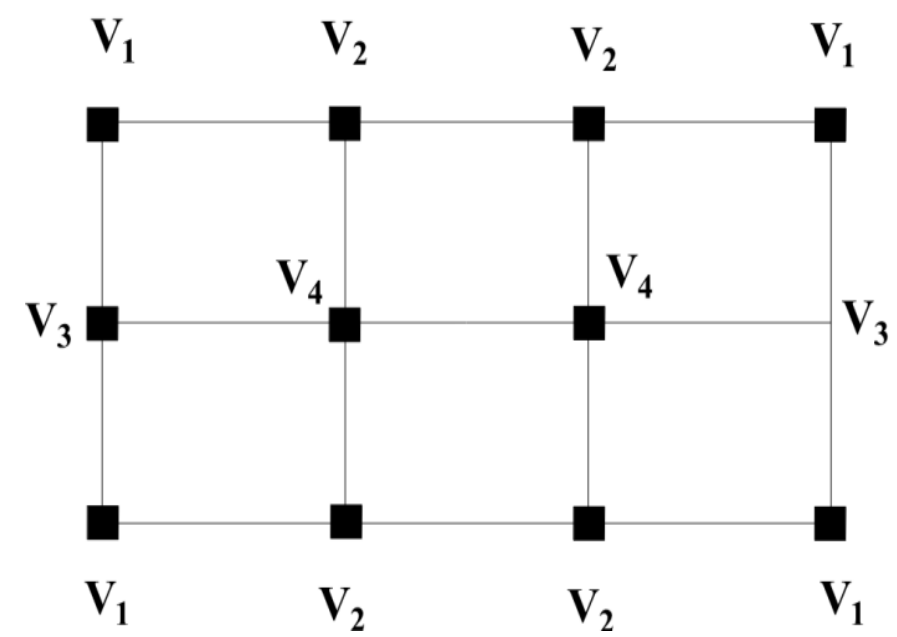

Figure 4. Location of Maximum Vertical Column Loads

From the ETABS analysis, $\mathrm{V}_{1}=571 \mathrm{kN}, \mathrm{V}_{2}=466 \mathrm{kN}, \mathrm{V}_{3}=439 \mathrm{kN}$ and $\mathrm{V}_{4}=605 \mathrm{kN}$

Therefore, the weight of the isolated structure $(\mathrm{W})=2(605)+4(571)+4(466)+2(439)$

$$
=6236 \mathrm{kN}
$$

Mass of the Total isolated structure, $\mathrm{m}=\frac{W}{g}=\frac{6236}{9.81}$

$$
=636 \mathrm{kNs}^{2} / \mathrm{m}
$$

$\mathrm{m}_{1}=151 \mathrm{kNs}^{2} / \mathrm{m}, \mathrm{m}_{2}=151 \mathrm{kNs}^{2} / \mathrm{m}$ and $\mathrm{m}_{3}=89 \mathrm{kNs}^{2} / \mathrm{m}$

Therefore, $\mathrm{k}_{1}=\mathrm{k}_{2=} 3.793 \times 10^{8} \mathrm{~N} / \mathrm{m} \quad \mathrm{k}_{3}=\quad 2.158 \times 10^{8} \mathrm{~N} / \mathrm{m}$.

Hence, $\mathrm{m}_{\mathrm{b}}=\mathrm{m}-\left(\mathrm{m}_{1}+\mathrm{m}_{2}+\mathrm{m}_{3}\right)$

$$
\begin{aligned}
& =636-(151+151+89) \\
& =245 \mathrm{kNs}^{2} / \mathrm{m}
\end{aligned}
$$

The stiffness of the bearing with respect to Maximum Vertical Column loads are presented in Table.4 
Table 9. Bearing stiffness

\begin{tabular}{|c|l|}
\hline $\begin{array}{l}\text { Maximum Vertical } \\
\text { Column Load (kN) }\end{array}$ & $\begin{array}{l}\text { Bearing } \\
\text { stiffness } \\
(\mathrm{kN} / \mathrm{m})\end{array}$ \\
\hline 605 & 390 \\
\hline 571 & 368 \\
\hline 466 & 300 \\
\hline 439 & 283 \\
\hline
\end{tabular}

Composite bearing stiffness $\mathrm{k}_{\mathrm{b}}=$ Stiffness of column in each joint at the base of the structure

$$
\begin{aligned}
& =2(390)+4(368)+4(300)+2(283) \\
& =4018 \mathrm{kN} / \mathrm{m} .
\end{aligned}
$$

The combined mass matrix and the combined stiffness matrix for the base isolated system respectively are given by Eqs. 3(b) and 3(c).[10]

Combined mass matrix, $\mathrm{M}_{\mathrm{c}}=\left[\begin{array}{cccc}\mathrm{m} & \mathrm{m}_{1} & \mathrm{~m}_{2} & \mathrm{~m}_{3} \\ \mathrm{~m}_{1} & \mathrm{~m}_{1} & 0 & 0 \\ \mathrm{~m}_{2} & 0 & \mathrm{~m}_{2} & 0 \\ \mathrm{~m}_{3} & 0 & 0 & \mathrm{~m}_{3}\end{array}\right]$
Combined stiffness matrix, $\mathrm{K}_{\mathrm{c}}=\left[\begin{array}{ccccc}\mathrm{k}_{\mathrm{b}} & 0 & 0 & 0 \\ 0 & \mathrm{k}_{1}+\mathrm{k}_{2} & -\mathrm{k}_{2} & 0 \\ 0 & -\mathrm{k}_{2} & \mathrm{k}_{2}+\mathrm{k}_{3} & -\mathrm{k}_{3} \\ 0 & 0 & -\mathrm{k}_{3} & \mathrm{k}_{3}\end{array}\right]$

The respective values of mass and stiffness are applied in the matrices and the application of MATLAB [13] is used and the mode values are determined and presented in Table.10

Table 10. Dynamic Properties of Base Isolated Building

\begin{tabular}{|l|l|l|l|l|}
\hline Mode & 1 & 2 & 3 & 4 \\
\hline Frequency (cps) & 0.3991 & 6.3627 & 10.9888 & 15.3830 \\
\hline \multirow{4}{*}{ Mode Shape } & 1.0000 & 1.0000 & 1.0000 & 1.0000 \\
\cline { 2 - 5 } & 0.0054 & -0.8431 & -2.5319 & -4.9689 \\
\cline { 2 - 5 } & 0.0087 & -1.7683 & -2.6689 & 2.2188 \\
\cline { 2 - 5 } & 0.0109 & -2.6864 & 1.6752 & -2.4753 \\
\hline
\end{tabular}

\section{Results and Discussions}

\subsection{Higher mode participation by varying the mass of the isolation system}

From the investigation, it is evident that there is a reduction in frequency with base isolation despite of the type of the isolator used. Nevertheless, the need to spot the variations in higher modes other than first mode of vibration is essential $[1,2,3]$. The behavior of modes in each case is presented in Table 11.

Table 11. Participation of Modes

\begin{tabular}{|l|c|c|c|c|c|}
\hline S.No & \multicolumn{2}{|l|}{$\begin{array}{l}\text { Relation between mass } \\
\text { of the isolation system } \\
\text { and mass of the } \\
\text { structure }\end{array}$} & \multicolumn{4}{|l|}{ Modes participating the vibration } \\
\hline & & Mode 1 & Mode 2 & Mode 3 & Mode 4 \\
\hline 1 & $\mathrm{~m}_{\mathrm{b}}=\mathrm{m}_{\mathrm{s}}$ & $\checkmark$ & $\checkmark$ & & \\
\hline 2 & $\mathrm{~m}_{\mathrm{b}}=\frac{1}{2} \mathrm{~m}_{\mathrm{s}}$ & $\checkmark$ & $\checkmark$ & $\checkmark$ & \\
\hline 3 & $\mathrm{~m}_{\mathrm{b}}=\frac{2}{3} \mathrm{~m}_{\mathrm{s}}$ & $\checkmark$ & $\checkmark$ & & \\
\hline 4 & $\mathrm{~m}_{\mathrm{b}}=\frac{1}{4} \mathrm{~m}_{\mathrm{s}}$ & $\checkmark$ & $\checkmark$ & $\checkmark$ & $\checkmark$ \\
\hline 5 & $\mathrm{~m}_{\mathrm{b}}=2 \mathrm{~m}_{\mathrm{s}}$ & $\checkmark$ & $\checkmark$ & & \\
\hline 6 & $\mathrm{~m}_{\mathrm{b}}=3 \mathrm{~m}_{\mathrm{s}}$ & $\checkmark$ & & & \\
\hline
\end{tabular}




\subsection{Identification of Higher mode participation using UBC-97 Provisions}

In the base isolation system, the first mode is called as the Isolation modes in which isolation system actively participate in vibration and in second mode which is called as structure mode; both isolation system and structure participate in vibration [10]. From this method 2 analysis, it is evident that the first and second mode actively participates in the vibration. Nevertheless, lesser participation is attained in other higher modes and similar observations are reported [10].

\section{Conclusion}

From the study, following conclusions are drawn

- The participation of all the modes is attained by considering mass of the isolation system equal to $1 / 4$ th of the mass of the structure which is the promising aspect to be considered. Moreover, the participation of first two modes which is highly attained in isolation system is reported in other cases. Furthermore, in second method, the isolation mode and structure modes actively participate in vibration.

- $\quad$ The need for higher mode participation is essential to reduce the drift and acceleration of the building. Hence, other factors which trigger for the participation of higher modes of vibration are to be identified.

\section{References}

1. Guerrini,G.andRestrepo, J. I. Higher-Mode Effects in Performance-Based Seismic Design of High-Rise Buildings, 78th Annual Convention of the Structural Engineers Association of California, San Diego, California, USA, 2019. Retrieved on March 18, Thursday, 2021 at 09:45:20 A.M.

2. Ma, C. F., Zhang, Y. H., Tan, P. and Zhou, F. L.Seismic Response of Base-Isolated High-Rise Buildings under Fully Non- stationary Excitation, Volume 2014, Article ID 401469. Retrieved from https://doi.org/10.1155/2014/401469on March 25, Thursday,

2021 at $03: 45: 27$ P.M

3. Tsai, C. S., Bo-Jen Chen, Tsu-Cheng Chiang and Wen-Shen Pong. Higher Mode Effect On Lateral Force Distributions For Base-Isolated Structures, 13th World Conference on Earthquake Engineering, Vancouver, B.C., Canada, August 1-6, 2004, Paper No. 736. Retrieved on March 19, Friday, 2021 at 12:45:20 P.M.

4. Khoshnoudian,F.and Nozadi,O.Effects of higher modes on vertical distribution of isolated structures under near field earthquakes, International Journal of Civil Engineering, Transaction A: Civil Engineering,11(2), 2013. Retrieved from ijce.iust.ac.ir on Friday, March $19^{\text {th }}$, 2021.

5. Lee, D. M. and Mediand, I.Base Isolation - An Historical Development, and the Influence of Higher Mode Responses, Bulletin of the New Zealand National Society for Earthquake Engineering, 11(4), 1978, 219-233.

6. Cici Jennifer Raj, J. and Suppiah, S. Seismic isolation using scrap tire rubber pads, Materials Today:Proceedings,2020. Retrieved from https://doi.org/10.1016/j.matpr.2020.09.176 on Wednesday, $22 \quad$ October 2019 06:27:10 PM.

7. Chaulagain, H., Rodrigues, H., Spacone, E. and Varum, H.Seismic Assessment of Three-Storey Residential Buildings in Nepal, 4th International Conference on Integrity, Reliability and Failure, 2013.Paper.Ref.No.4755. Retrieved on November 25, Wednesday, 2021 at 11:50:20 A.M.

8. Uniform Building Code (UBC-97), Earthquake Regulations for Seismic Isolated

9. Structures, Uniform Building Code, Volume 2, Whittier, CA, 1997.

10. Computers and Structures, Inc, ETABS Integrated Building Design Software User Interface Reference Manual, Berkeley, California, USA, January 2002.

11. Villaverde, R. Fundamental Concepts of Earthquake Engineering, CRC Press, Boca Raton, 2009. Retrieved from https://www.academia.edu/36052396/. Fundamentals_of_Earthquake_Engg_Roberto_Villaverde (on 17 May 2020,07:14:34).

12. New Zealand Society for Earthquake Engineering, Guidelines for the design of seismic isolation system for building (Draft), 2019. Retrieved from www.nzsee.org.nz/publications/designof-seismic-isolation-systems- for-buildings on 15 June, Monday, 2020 at 08:18:34 A.M.

13. Kelly, J. M. and Naeim, F. Design of Seismic Isolated Structure from theory of Practice, John Wiley and Sons, 1999.

14. Jain, A. K. Dynamics of Structures with MATLAB Applications, Pearson Education India, 2016.

15. Kelly,J. M. and Eeeri, M. Base isolation linear theory and design, Earthq. Spectra 6(2) (1990) 223-244

16. Chen, W. F. and Scawthorn,C. Earthquake Engineering Handbook, $2^{\text {nd }}$ edition, CRC Press, 2017. 